\title{
Sulforaphane inhibits the interferon- $\gamma$-induced expression of MIG, IP-10 and I-TAC in INS-1 pancreatic $\beta$-cells through the downregulation of IRF-1, STAT-1 and PKB
}

\author{
YU-KYOUNG PARK ${ }^{1}$, MAHESH RAMALINGAM $^{1}$, SHIN KIM $^{2}$, \\ BYEONG-CHURL JANG ${ }^{1}$ and JONG WOOK PARK ${ }^{2,3}$
}

\author{
Departments of ${ }^{1}$ Molecular Medicine and ${ }^{2}$ Immunology, College of Medicine, and ${ }^{3}$ Institute for \\ Cancer Research, Keimyung University, Dalseo-gu, Daegu 42601, Republic of Korea
}

Received June 10, 2016; Accepted June 1, 2017

DOI: $10.3892 /$ ijmm.2017.3054

\begin{abstract}
Sulforaphane (SFN) is a dietary isothiocyanate abundantly available in cruciferous vegetables and has been shown to possess anti-inflammatory and immunomodulatory activities. Chemokines are important mediators of inflammation and immune responses due to their ability to recruit and activate macrophages and leukocytes. To date, little is known about the SFN-mediated regulation of chemokine expression in pancreatic $\beta$-cells. In this study, we investigated the inhibitory effects and mechanisms of SFN on the interferon- $\gamma($ IFN- $\gamma$ )-induced expression of a subset of chemokines, including monokine induced by IFN- $\gamma$ (MIG), IFN-inducible protein of $10 \mathrm{kDa}$ (IP-10) and IFN-inducible T-cell alpha chemoattractant (I-TAC), in INS-1 cells, a rat pancreatic $\beta$-cell line. Notably, IFN- $\gamma$ treatment led to an increase in the mRNA expression levels of MIG, IP-10 and I-TAC in the INS-1 cells. However, SFN strongly blocked the mRNA expressions of MIG, IP-10 and I-TAC induced by IFN- $\gamma$ in INS-1 cells. On the mechanistic level, SFN significanlty decreased not only the mRNA expression levels of interferon regulatory factor-1 (IRF-1), but also the phosphorylation levels of signal transducer and activator of transcription-1 (STAT-1) and protein kinase $\mathrm{B}$ (PKB) which were induced by IFN- $\gamma$ in the INS-1 cells. Pharmacological inhibition experiments further revealed that treatment with JAK inhibitor I weakly inhibited the IFN- $\gamma$-induced expression of IP-10, whereas it strongly suppressed the IFN- $\gamma$-induced expression of MIG and I-TAC
\end{abstract}

Correspondence to: Professor Jong Wook Park, Department of Immunology, College of Medicine, Keimyung University, 1095 Dalgubeoldaero, Dalseo-gu, Daegu 42601, Republic of Korea E-mail: j303nih@dsmc.or.kr

Professor Byeong-Churl Jang, Department of Molecular Medicine, College of Medicine, Keimyung University, 1095 Dalgubeoldaero, Dalseo-gu, Daegu 42601, Republic of Korea

E-mail: jangbc123@gw.kmu.ac.kr

Key words: sulforaphane, interferon- $\gamma$, T-cell chemokines, signal transducer and activator of transcription-1, interferon regulatory factor-1, INS-1 cells in the INS-1 cells. Moreover, treatment with LY294002, a PI3K/PKB inhibitor, was able to slightly repress IFN- $\gamma$-induced expressions of MIG and I-TAC, but not IP-10, in INS-1 cells. Importantly, the IFN- $\gamma$-induced increase in the expression levels of MIG, IP-10 and I-TAC in the INS-1 cells was strongly inhibited by SFN, but not by other natural substances, such as curcumin, sanguinarine, resveratrol, triptolide and epigallocatechin gallate (EGCG), suggesting the specificity of SFN in downregulating the levels of these chemokines. To the best of our knowledge, these results collectively demonstrate for the first time that SFN strongly inhibits the IFN- $\gamma$-induced expression of MIG, IP-10 and I-TAC in INS-1 cells and this inhibition is, at least in part, mediated through the reduced expression and phosphorylation levels of IRF-1, STAT-1 and PKB.

\section{Introduction}

Chemokines have been shown to control the migratory behavior of several cell types, including lymphocytes. Helper T-lymphocytes (Th1), cellular mediators of adaptive immune responses, produce interferon- $\gamma($ IFN- $\gamma$ ) that can stimulate macrophages, epithelial cells and tissue parenchymal cells to express $\mathrm{CXC}$ chemokines, such as monokine induced by IFN- $\gamma$ (MIG), IFN-inducible protein of $10 \mathrm{kDa}$ (IP-10) and IFN-inducible T-cell alpha chemoattractant (I-TAC) (1-5). It has also been shown that Th1 cells preferentially express CXC chemokine receptor 3 (CXCR3), which binds IP-10, I-TAC and MIG with high affinity, and the binding of CXCR3 ligands to the receptor produces cellular signals important for chemotaxis and the activation of T-cells (6,7), suggesting that the expression of IP-10, MIG and I-TAC is important in T-lymphocyte recruitment and host defense following various infections.

Immune responses that contribute to host defense are also capable of causing tissue injury and disease under pathological conditions. There is increasing evidence to indicate that during the development of type 1 diabetes, autoreactive T-cells transverse the endothelium and matrix barriers to infiltrate pancreatic islets and these autoreactive T-cells target a number of islet cell autoantigens, including insulin (8), glutamic acid decarboxylase (9) and protein tyrosine phosphatase (10). The infiltration of immune cells in islets, termed insulitis, increases 
progressively once it begins and leads to $\beta$-cell destruction, insulin deficiency and clinical type 1 diabetes (11). It has been reported that insulitic lesions are characterized by the presence of $\beta$-cells, elevated levels of chemokines, such as IP-10, and the infiltration of lymphocytes expressing CXCR3 (12), which may suggest that IFN- $\gamma$-inducible chemokines may play crucial roles in the initiation of insulitis.

Sulforaphane (1-isothiocyanato-4-methylsulfinylbutane, SFN) is a dietary isothiocyanate found abundantly in cruciferous vegetables and has been shown to possess anti-inflammatory and immune modulatory activities $(13,14)$. For instance, SFN has been shown to suppress the bacterial lipopolysaccharide-mediated expression of inducible nitric oxide synthase, cyclooxygenase 2 , interleukin- 1 and tumor necrosis factor- $\alpha$ (TNF- $\alpha$ ) in RAW 264.7 and peritoneal macrophages $(13,15,16)$. It has also been reported that SFN inhibits TNF- $\alpha$-induced nuclear factor- $\kappa \mathrm{B}(\mathrm{NF}-\kappa \mathrm{B})$ activation, which leads to the reduced expression of NF- $\mathrm{kB}$ regulated gene products, such as matrix metalloproteinase-9 (17), further supporting its anti-inflammatory activity. As MIG, IP-10 and I-TAC play an important role in T-cell recruitment for the initiation of adaptive immunity, therapies aiming at reducing the levels of these chemokines are of great interest.

In this study, we primarily investigated the effects of IFN- $\gamma$ on the expression levels of MIG, IP-10 and I-TAC in INS-1 cells, a rat pancreatic $\beta$-cell line, and secondly determined whether SFN modulates the IFN- $\gamma$-induced expression of MIG, IP-10 and I-TAC in INS-1 cells. To the best of our knowledge, we report for the first time, the ability of SFN to strongly inhibit the IFN- $\gamma$-induced mRNA expression of MIG, IP-10 and I-TAC in INS-1 cells through the modulation of the expression and/or phosphorylation levels of interferon regulatory factor (IRF)-1, signal transducer and activator of transcription-1 (STAT-1) and protein kinase $\mathrm{B}$ (PKB).

\section{Materials and methods}

Materials. Recombinant rat IFN- $\gamma$ was obtained from R\&D Systems (Minneapolis, MN, USA). JAK inhibitor I (a pan-JAK inhibitor) and LY294002 (a PI3K/PKB inhibitor) were obtained from Calbiochem (Billerica, MA, USA) and Biomol (Plymouth Meeting, PA, USA), respectively. Anti-pSTAT-1 (\#9171), anti-STAT-1 (\#9175), anti-p-PKB (\#9271) and anti-PKB (\#9272) antibodies were purchased from Cell Signaling Technology (Boston, MA, USA). $\beta$-actin antibody (A5441) was purchased from Sigma (St. Louis, MO, USA). PCR primers were purchased from Bioneer (Daejeon, Korea). RPMI-1640 was purchased from Gibco-BRL (Carlsbad, CA, USA). Other chemicals, including SFN, were obtained from Sigma.

Cell culture. The INS-1 cells, an immortalized rat pancreatic $\beta$-cell line (Korean Cell Line Bank, Seoul, Korea), were cultured in RPMI-1640 medium containing $11.2 \mathrm{mM}$ glucose, $2 \mathrm{mM}$ l-glutamine, $10 \%$ heat-inactivated fetal bovine serum, $1 \mathrm{mM}$ pyruvate, $10 \mathrm{mM}$ HEPES, $50 \mu \mathrm{M} 2$-mercaptoethanol and $100 \mu \mathrm{g} / \mathrm{ml}$ streptomycin.

Treatment of the INS-1 cells with IFN- $\gamma, S F N$, and/or other agents. The INS-1 cells were treated with or without IFN- $\gamma$ at various concentrations $(0,0.25,0.5,1,2,5$ or $10 \mathrm{ng} / \mathrm{ml})$ and for different periods of time $(0,0.5,2,6$ or $24 \mathrm{~h})$. The INS-1 cells were also treated with or without IFN- $\gamma(10 \mathrm{ng} / \mathrm{ml})$ in the absence or presence of SFN at various concentrations $(0,5,10$ or $25 \mu \mathrm{M}$ ) for $6 \mathrm{~h}$. For pharmacological inhibition experiments, the INS-1 cells were treated with or without IFN- $\gamma(10 \mathrm{ng} / \mathrm{ml})$ in the absence or presence of JAK inhibitor I (JI, $0.1 \mu \mathrm{M})$, a pan-JAK inhibitor, or LY294002 (LY, $25 \mu \mathrm{M}$ ), a PI3K/PKB inhibitor, for $6 \mathrm{~h}$. For comparison, the INS-1 cells were treated with or without IFN- $\gamma(10 \mathrm{ng} / \mathrm{ml})$ in the absence or presence of SFN $(25 \mu \mathrm{M})$, curcumin $(10 \mu \mathrm{M})$, sanguinarine $(500 \mathrm{nM})$, resveratrol $(25 \mu \mathrm{M})$, triptolide $(40 \mathrm{nM})$ or EGCG $(25 \mu \mathrm{M})$ for $6 \mathrm{~h}$.

Reverse transcription-polymerase chain reaction (RT-PCR). Total RNA was isolated using TRIzol reagent (Life Technologies, Gaithersburg, MD, USA), and cDNA was prepared using M-MLV reverse transcriptase (Gibco-BRL, Carlsbad, CA, USA) according to the manufacturers' instructions. The following primers were used for the amplification of rat MIG, IP-10, I-TAC, IRF-1, IRF-2 and glyceraldehyde 3-phosphate dehydrogenase (GAPDH): MIG sense, 5'-CAG CCA AGG CAC ATT CCA CT-3' and antisense, 5'-GAT GCA GAG CGC TTG TTG GT-3'; IP-10 sense, 5'-CAA GTG CTG CTG TCG TTC TC-3' and antisense, 5'-TCT CTC TGC TGT CCA TCG GT-3'; I-TAC sense, 5'-AGA TCA CCA GAG CCA CAG CA-3' and antisense, 5'-ATC CGA CCT CCT AGC GAG TT-3'; IRF-1 sense, 5'-AAG TGA AGG ACC AGA GCA GG-3' and antisense, 5'-CTG TTG CAG CTT CAG AGG TG-3'; IRF-2 sense, 5'-ACA ACG CCT TCA GAG TCT AC-3' and antisense, 5'-TGC ATA GGA AGA CAC AGG AG-3'; and GAPDH sense, 5'-CCG TAT CGG ACG CCT GGT TA-3' and antisense, 5'-TGG TGG TGC AGG ATG TAT TG-3'. The PCR amplification was carried out using the following cycling conditions: $94^{\circ} \mathrm{C}$ for 3 min followed by $17-25$ cycles of $94^{\circ} \mathrm{C}$ for $45 \mathrm{sec}, 58^{\circ} \mathrm{C}$ for $45 \mathrm{sec}, 72^{\circ} \mathrm{C}$ for $45 \mathrm{sec}$, and a final extension at $72^{\circ} \mathrm{C}$ for $5 \mathrm{~min}$. The amplified products were separated by electrophoresis on a $1.5 \%$ agarose gel and detected under UV light.

Preparation of whole cell lysates. The INS-1 cells were washed with cold phosphate-buffered saline (PBS) and lysed in a modified RIPA buffer (50 mM Tris- $\mathrm{HCl} \mathrm{pH} 7.4,1 \% \mathrm{NP}-40$, $0.25 \%$ Na-deoxycholate, $150 \mathrm{mM} \mathrm{NaCl}, 1 \mathrm{mM} \mathrm{Na}_{3} \mathrm{VO}_{4}$ and $1 \mathrm{mM} \mathrm{NaF})$ containing protease inhibitors $(100 \mu \mathrm{M}$ phenylmethylsulfonyl fluoride, $10 \mu \mathrm{g} / \mathrm{ml}$ leupeptin, $10 \mu \mathrm{g} / \mathrm{ml}$ pepstatin and $2 \mathrm{mM}$ EDTA) on ice for $15 \mathrm{~min}$. The cell lysates were collected and centrifuged at $10,000 \mathrm{x}$ g at $4^{\circ} \mathrm{C}$ for $10 \mathrm{~min}$. The supernatant was saved and protein concentrations were determined using Bradford reagent (Bio-Rad, Hercules, CA, USA).

Western blot analysis. Proteins $(50 \mu \mathrm{g})$ were separated by sodium dodecyl sulfate-polyacrylamide gel electrophoresis (SDS-PAGE; 10\%) and transferred onto Immobilon-P membranes. The membranes were washed with TBS (10 mM Tris, $150 \mathrm{mM} \mathrm{NaCl}$ ) supplemented with $0.05 \%(\mathrm{v} / \mathrm{v})$ Tween-20 (TBST) followed by blocking with TBST containing $5 \%(\mathrm{w} / \mathrm{v})$ non-fat dried milk. The membranes were incubated overnight with antibodies specific for p-STAT-1 $(1: 1,000)$, STAT-1 $(1: 1,000)$, p-PKB $(1: 2,000)$ or PKB $(1: 1,000)$ at $4{ }^{\circ} \mathrm{C}$. The membranes were then exposed to secondary antibodies [anti-rabbit $\operatorname{IgG}$ (sc-2004) and anti-mouse $\operatorname{IgG}$ (sc-2005); purchased from Santa Cruz Biotechnology, Delaware, CA, USA] 

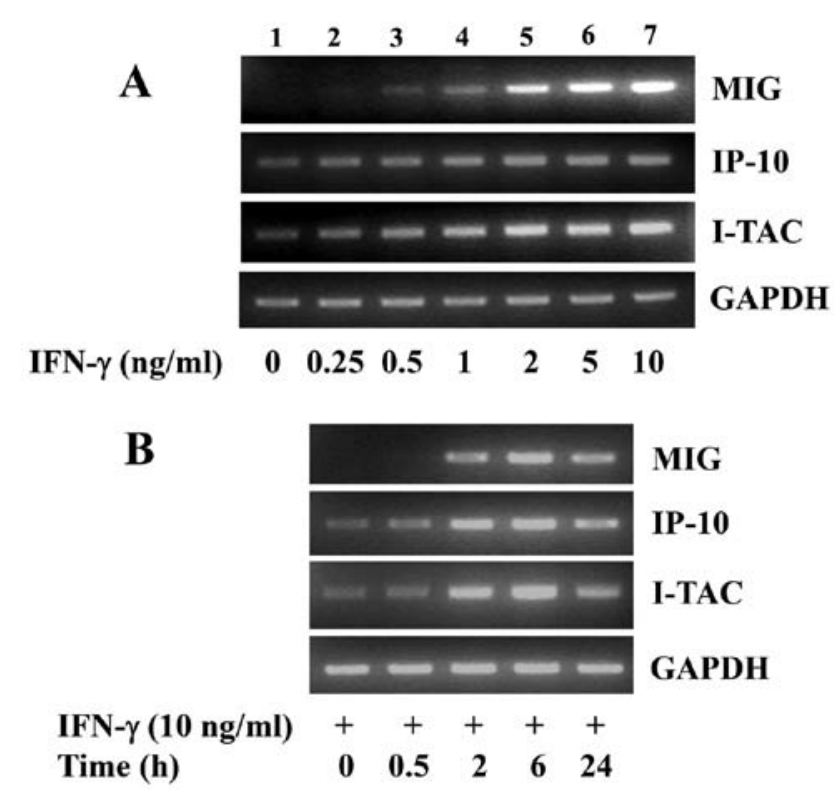

Figure 1. Effect of IFN- $\gamma$ on the mRNA expression levels of monokine induced by IFN- $\gamma$ (MIG), IFN-inducible protein of $10 \mathrm{kDa}$ (IP-10) and IFN-inducible $\mathrm{T}$ cell alpha chemoattractant (I-TAC) in INS-1 cells. (A) INS-1 cells were treated with or without interferon- $\gamma($ IFN- $\gamma)$ at the indicated concentrations for $6 \mathrm{~h}$. Total RNA was prepared and used for RT-PCR with specific primers for MIG, IP-10, I-TAC or glyceraldehyde 3-phosphate dehydrogenase (GAPDH). (B) INS-1 cells were treated with or without IFN- $\gamma(10 \mathrm{ng} / \mathrm{ml})$ for the indicated time periods. At each time point, total RNA was prepared and used for RT-PCR with specific primers for MIG, IP-10, I-TAC or GAPDH. The blots in (A or B) are representative of 3 independent experiments.

coupled to horseradish peroxidase for $2 \mathrm{~h}$ at room temperature. $\beta$-actin (dilution, 1:10,000) was used as an internal control. The membranes were washed 3 times with TBST at room temperature. Immunoreactivities were detected by ECL reagents.

\section{Results}

Dose-and time-dependent increase in the mRNA levels of the T-cell-specific chemokines, MIG, IP-10 and I-TAC, in INS-I cells treated with IFN- $\gamma$. Initially, we investigated the effects of treatment with various concentrations of IFN- $\gamma$ for $6 \mathrm{~h}$ on the expression of T-cell-specific chemokines, including MIG, IP-10 and I-TAC in INS-1 cells. As shown in Fig. 1A, compared with the control (lane 1), $6 \mathrm{~h}$ of treatment with IFN- $\gamma$ led to a concentration-dependent increase in the mRNA levels of MIG, IP-10 and I-TAC in the INS-1 cells (lanes 2-7). Due to the strong induction of the MIG, IP-10 and I-TAC mRNA expression levels in INS-1 cells, the concentration of $10 \mathrm{ng} / \mathrm{ml}$ of IFN- $\gamma$ was selected for use in further experiments. Time course experiments were then carried out to determine the time of induction of chemokine expression in INS-1 cells in response to IFN- $\gamma(10 \mathrm{ng} / \mathrm{ml})$. As shown in Fig. 1B, treatment with IFN- $\gamma$ led to a time-dependent increase in the mRNA levels of MIG, IP-10 and I-TAC in the INS-1 cells, in which $6 \mathrm{~h}$ of treatment with IFN- $\gamma$ was maximal for the induction of the expression of these chemokines. The mRNA expression of the control, GAPDH, remained constant under these experimental conditions.

Blockage of the IFN- $\gamma$-induced expression of MIG, IP-10 and I-TAC in INS-1 cells by SFN. We then determined the effects

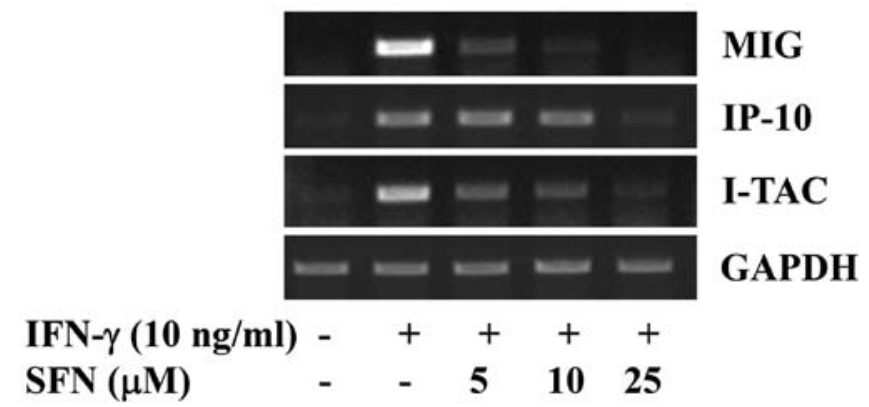

Figure 2. Effect of sulforaphane (SFN) on interferon- $\gamma$ the (IFN- $\gamma$ )-induced mRNA expression of monokine induced by IFN- $\gamma$ (MIG), IFN-inducible protein of $10 \mathrm{kDa}$ (IP-10) and IFN-inducible T cell alpha chemoattractant (I-TAC) in INS-1 cells. INS-1 cells were treated with or without IFN- $\gamma(10 \mathrm{ng} /$ $\mathrm{ml}$ ) in the absence or presence of SFN at the indicated concentrations for $6 \mathrm{~h}$. Total RNA was prepared and used for RT-PCR with specific primers for MIG, IP-10, I-TAC or glyceraldehyde 3-phosphate dehydrogenase (GAPDH). The blots are representative of 3 independent experiments.

of treatment with various concentrations of SFN on the IFN- $\gamma$ induced expression of MIG, IP-10 and I-TAC in INS-1 cells. As shown in Fig. 2, treatment with SFN resulted in a dosedependent blockage of the IFN- $\gamma$-induced expression of MIG, IP-10 and I-TAC in the INS-1 cells. Of note, treatment with SFN at $25 \mu \mathrm{M}$ was able to almost completely inhibit the IFN- $\gamma$ induced expression of MIG, IP-10 and I-TAC. The mRNA expression of the control, GAPDH, remained unaltered under these experimental conditions.

Downregulation of the IFN- $\gamma$-induced $m R N A$ expression levels of IRF-1 and phosphorylation levels of STAT-1 and PKB in INS-1 cells by $S F N$. It has been shown that IFN- $\gamma$ activity is mediated through the activation of the JAK/STAT signaling pathway, which further triggers the activation of many downstream effectors, such as PKB, and the activation of these signaling pathways or components is necessary for the transcriptional induction of IFN- $\gamma$ target genes, including chemokines $(18,19)$. There is also strong evidence to indicate that the IFN- $\gamma$ induced expression of MIG, IP-10 and I-TAC occurs through an STAT-1/IRF-1-dependent mechanism, which may play an important role in the infiltration of leukocytes into tissue (20). This promptly led us to investigate the effects of IFN- $\gamma$ and/ or SFN on the activation (phosphorylation) of STAT-1 and PKB, and on the expression of IRF-1 and IRF-2 in the INS-1 cells. As shown in Fig. 3A, compared with the control (lane 1), treatment with IFN- $\gamma$ increased the phosphorylation levels of both STAT-1 and PKB in the INS-1 cells (lane 2). However, treatment with SFN led to a concentration-dependent reduction in the phosphorylation levels of these proteins induced by IFN- $\gamma$ in the INS-1 cells (lanes 3-5). The maximal inhibition of the IFN- $\gamma$-induced phosphorylation of STAT-1 and PKB was observed by treatment with SFN at $25 \mu \mathrm{M}$. The total protein expression levels of STAT-1 and PKB remained constant by treatment with or without IFN- $\gamma$ in the absence or presence of SFN, suggesting that IFN- $\gamma$ or SFN treatment alters the phosphorylation levels of pre-existing STAT-1 and PKB in the INS-1 cells without leading to de novo protein synthesis. As shown in Fig. 3B, compared with control (lane 1), treatment with IFN- $\gamma$ increased the mRNA expression levels of both 
A

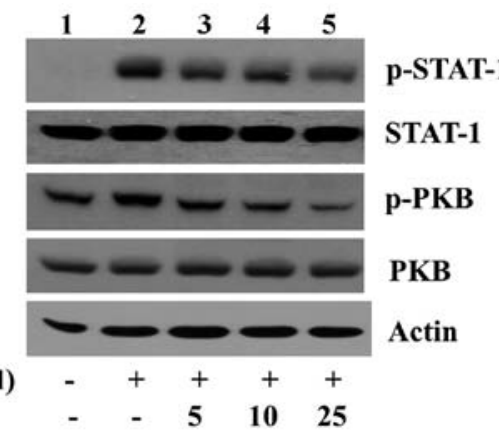

IFN- $\gamma(10 \mathrm{ng} / \mathrm{ml})$ $\operatorname{SFN}(\mu \mathrm{M})$

B

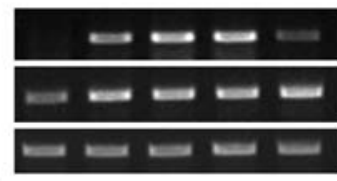

IRF-1

IRF-2

GAPDH

IFN- $\gamma(10 \mathrm{ng} / \mathrm{ml})$ SFN $(\mu \mathrm{M})$

(1)

$\begin{array}{cccc}+ & + & + & + \\ - & 5 & 10 & 25\end{array}$

Figure 3. Effect of sulforaphane (SFN) on the interferon- $\gamma$ (IFN- $\gamma$ )-induced activation (phosphorylation) of signal transducer and activator of transcription-1 (STAT-1) and protein kinase B (PKB) and the mRNA expression of interferon regulatory factor-1/2 (IRF-1/2) in INS-1 cells. (A) INS-1 cells were treated with or without IFN- $\gamma(10 \mathrm{ng} / \mathrm{ml})$ in the absence or presence of SFN at the indicated concentrations for $6 \mathrm{~h}$. Whole cell lysates were prepared and analyzed by western blot analysis with specific antibodies to p-STAT-1, STAT-1, p-PKB or PKB. p-STAT-1, phosphorylated STAT-1; STAT-1, total STAT-1; p-PKB, phosphorylated PKB; PKB, total PKB. The blots in (A) are representative of 3 independent experiments. (B) INS-1 cells were treated with or without IFN- $\gamma(10 \mathrm{ng} / \mathrm{ml})$ in the absence or presence of SFN at the indicated concentrations for $6 \mathrm{~h}$. Total RNA was prepared and used for RT-PCR with specific primers for interferon regulatory factor-1 (IRF-1), IRF-2 or glyceraldehyde 3-phosphate dehydrogenase (GAPDH). The blots in (B) are representative of 3 independent experiments.

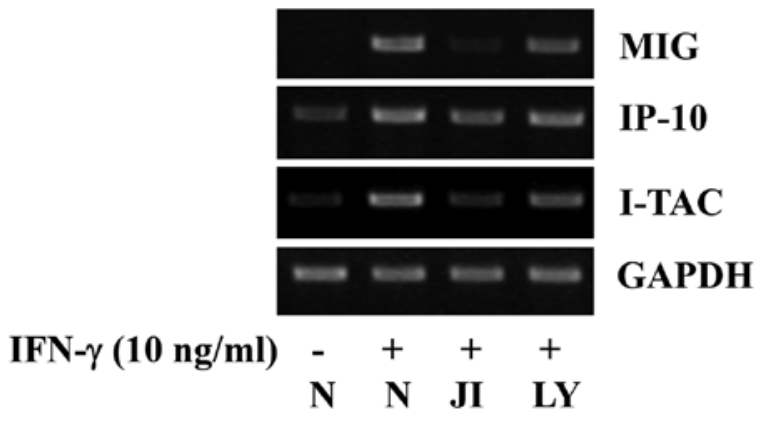

Figure 4. Effect of interferon- $\gamma$ (IFN- $\gamma$ ) and/or JAK inhibitor I or LY294002 on the mRNA expression of monokine induced by IFN- $\gamma$ (MIG), IFN-inducible protein of $10 \mathrm{kDa}$ (IP-10), and IFN-inducible T cell alpha chemoattractant (I-TAC) in INS-1 cells. INS-1 cells were treated with or without IFN- $\gamma$ $(10 \mathrm{ng} / \mathrm{ml})$ in the absence or presence of JAK inhibitor I (JI, $0.1 \mu \mathrm{M})$, a panJAK inhibitor, or LY294002 (LY, $25 \mu \mathrm{M}$ ), a PI3K/PKB inhibitor, for $6 \mathrm{~h}$. Total RNA was prepared and used for RT-PCR with specific primers for MIG, IP-10, I-TAC or glyceraldehyde 3-phosphate dehydrogenase (GAPDH). The blots are representative of 3 independent experiments.

IRF-1 and IRF-2 in the INS-1 cells (lane 2). However, treatment with SFN, particularly at $25 \mu \mathrm{M}$, strongly reduced the mRNA levels of IRF-1 in the INS-1 cells (lane 5). SFN at the concentrations tested had no effect on the mRNA expression of IRF-2 induced by IFN- $\gamma$ in the cells. The mRNA expression of the control, GAPDH, remained constant by treatment without or with IFN- $\gamma$ in the absence of presence of SFN.

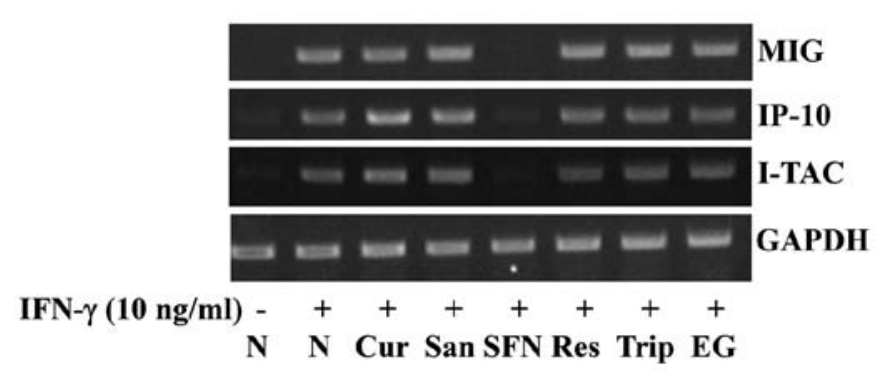

Figure 5. Effect of sulforaphane (SFN), curcumin (Cur), sanguinarine (San), resveratrol (Res), triptolide (Trip) or epigallocatechin gallate (EGCG; EG) on the interferon- $\gamma($ IFN- $\gamma$ )-induced expression of monokine induced by IFN- $\gamma$ (MIG), IFN-inducible protein of $10 \mathrm{kDa}$ (IP-10) and IFN-inducible T cell alpha chemoattractant (I-TAC) in INS-1 cells. INS-1 cells were treated with or without IFN- $\gamma(10 \mathrm{ng} / \mathrm{ml})$ in the absence or presence of SFN $(25 \mu \mathrm{M})$, curcumin $(10 \mu \mathrm{M})$, sanguinarine $(500 \mathrm{nM})$, resveratrol $(25 \mu \mathrm{M})$, triptolide $(40 \mathrm{nM})$ or EGCG $(25 \mu \mathrm{M})$ for $6 \mathrm{~h}$. Total RNA was prepared and used for RT-PCR with specific primers for MIG, IP-10, I-TAC or glyceraldehyde 3-phosphate dehydrogenase (GAPDH). The blots are representative of 3 independent experiments.

Role of JAK/STAT-1 and PI3K/PKB in the IFN- $\gamma$-induced expressions of MIG, IP-10 and I-TAC in the INS-1 cells. In order to determine the role of STAT-1 and/or PKB in the IFN- $\gamma$-induced expression of MIG, IP-10 and I-TAC, as well as in the suppressive effects of SFN on the IFN- $\gamma$-induced expression of MIG, IP-10 and I-TAC in the INS-1 cells, we then performed pharmacological inhibition experiments with the pan-JAK inhibitor, JAK inhibitor I and the PI3K/PKB inhibitor, LY294002. As shown in Fig. 4, treatment with JAK inhibitor I strongly blocked the IFN- $\gamma$-induced expression of MIG and I-TAC, but weakly inhibited the IFN- $\gamma$-induced expression of IP-10 in the INS-1 cells. Treatment with LY294002 also slightly reduced the mRNA levels of MIG and I-TAC, but not those of IP-10, which were induced by IFN- $\gamma$ in the INS-1 cells. The mRNA expression of the control, GAPDH, remained constant by treatment with or without IFN- $\gamma$ in the absence of presence of JAK inhibitor I or LY294002.

Comparison of the effects of SFN and other natural substances on the IFN- $\gamma$-induced expression of MIG, IP-10 and I-TAC in INS-1 cells. To examine the specificity, we then compared the effects of SFN and other natural substances, including curcumin, sanguinarine, resveratrol, triptolide and EGCG, on IFN- $\gamma$-induced expressions of MIG, IP-10 and I-TAC in INS-1 cells. As shown in Fig. 5, as expected, treatment with SFN strongly inhibited the mRNA expression levels of MIG, IP-10 and I-TAC induced by IFN- $\gamma$ in the INS-1 cells. However, treatment with curcumin (Cur), sanguinarine (San), resveratrol (Res), triptolide (Trip) or epigallocatechin gallate (EGCG; EG) did not affect the IFN- $\gamma$-induced expressions of MIG, IP-10 and I-TAC in the INS-1 cells.

\section{Discussion}

Evidence suggests elevated levels of CXC chemokines in pathological conditions of the pancreas, including pancreatic infection (21) or autoimmune insulitis (22). The increased expression of IP-10 and the infiltration of lymphocytes 
expressing CXCR3 has been observed in all pancreatic lesions of patients with type 1 diabetes, compared with no or low expression of IP-10 and CXCR3 in the pancreas of non-diabetic control subjects (12). The enhanced expression of chemokines within pancreatic islets is likely to contribute to islet inflammation by controlling the recruitment and the activation of macrophages, neutrophils and Th1. Thus, any compound that can inhibit the excessive expression of chemokines in pancreatic $\beta$-cells may have preventive and/or therapeutic potential against islet inflammation and related diseases.

IFN- $\gamma$ is a pro-inflammatory cytokine and mediates inflammatory and immune responses. Reportedly, type I and II interferons, including IFN- $\gamma$, are also associated with islet inflammation and $\beta$-cell death and dysfunction (23-25). At present, the IFN- $\gamma$-mediated induction of chemokine expression in pancreatic $\beta$-cells is not well known. In this study, we demonstrated that treatment with IFN- $\gamma$ largely stimulated the mRNA expression levels of MIG, IP-10 and I-TAC in INS-1 cells at the concentration of $10 \mathrm{ng} / \mathrm{ml}$ (Fig. 1). IFN- $\gamma$ activity is mediated through its cognate receptors, IFN- $\gamma \mathrm{R} 1$ and IFN- $\gamma \mathrm{R} 2$, which further trigger the activation of the JAK-STAT signaling pathway (26). Upon IFN- $\gamma$ binding to the IFN- $\gamma \mathrm{R} 1$ and IFN- $\gamma$ R2, JAK1 and JAK2 associated with the receptors are activated, leading to STAT-1 phosphorylation (on tyrosine 701) and activation. Active STAT-1 then undergoes dimerization and the dimeric complex translocates to the nucleus where it regulates gene expression by binding to $\gamma$-activated sequence elements in the promoters of IFN- $\gamma$-regulated genes, including chemokines $(18,27,28)$. These results point out the critical role of JAK-STAT-1 activity in the transcriptional upregulation of chemokines in response to IFN- $\gamma$ exposure. In addition to JAK-STAT activity, the PI3K/PKB signaling pathway has been reported to be important for IP-10 gene expression (19). In the present study, IFN- $\gamma$ treatment largely increased the phosphorylation levels of STAT-1 and PKB in the INS-1 cells (Fig. 3A, lane 2), but the blockage of JAK/STAT-1 activity by JAK inhibitor I or PI3K/PKB activity by LY294002 strongly or weakly abrogated the ability of IFN- $\gamma$ to induce the mRNA expression of MIG, IP-10 and I-TAC in INS-1 cells (Fig. 4, lanes 3 or 4). These results suggest that the activation of the JAK/STAT-1 and PI3K/PKB signaling proteins is critical for the IFN- $\gamma$-induced expression of MIG, IP-10 and I-TAC in INS- 1 cells.

SFN is an isothiocyanate substance abundantly found in cruciferous vegetables, such as broccoli and brussel sprouts, and has been shown to possess anti-inflammatory, anti-cancerous, and immunomodulatory effects $(13,14,29,30)$. Previously, the SFN-mediated regulation of chemokines, such as CCL17 and CCL22, through heme oxygenase-1 and NF- $\mathrm{KB}$ in human keratinocytes has been reported (31). At present, neither the inhibitory effect, nor the mechanisms of action of SFN as regards the expression of T-cell chemokines induced by IFN- $\gamma$ in pancreatic $\beta$-cells are known. In this study, we demonstrated that SFN at the $25 \mu \mathrm{M}$ concentration strongly inhibited not only the IFN- $\gamma$-induced expression of MIG, IP-10 and I-TAC (Fig. 2), but also the IFN- $\gamma$-induced activation (phosphorylation) of STAT-1 and PKB signaling proteins (Fig. 3A, lane 5) in INS-1 cells. Considering the positive role of STAT- 1 and PKB activities in the IFN- $\gamma$-induced expression of MIG, IP-10, and/ or I-TAC in INS-1 cells herein (Fig. 4), it is evident that the suppressive effects of SFN on the IFN- $\gamma$-induced expression of MIG, IP-10, and I-TAC in INS-1 cells is, at least in part, attributable to the inhibition of STAT-1 and PKB signaling proteins.

The activation of STAT-1 induced by IFN- $\gamma$ leads to the transcriptional induction of a number of genes, including IRF-1, a transcription factor involved in the transcription of many antiviral and anti-apoptotic genes (32). There is of interest recent evidence suggesting that the transcriptional upregulation of MIG, IP-10 and I-TAC genes occurs through an STAT-1/IRF-1-dependent mechanism (20). The present study revealed that IFN- $\gamma$ treatment largely upregulated the transcript levels of IRF-1 and IRF-2, while SFN treatment, particularly at $25 \mu \mathrm{M}$ strongly suppressed the IFN- $\gamma$-induced mRNA expression of IRF-1, but not that of IRF-2 in the INS-1 cells (Fig. 3B). It is thus likely that the downregulation of the STAT-1/IRF-1 signaling pathways further contributes to the suppressive effects of SFN on the IFN- $\gamma$-induced expression of MIG, IP-10 and I-TAC in INS-1 cells.

An interesting finding of the present study is the specificity of SFN in inhibiting the IFN- $\gamma$-induced expression of MIG, IP-10 and I-TAC in INS-1 cells, as evidenced by that unlike SFN, other natural substances with known anti-inflammatory and/or immune modulatory activities, such as curcumin (33), sanguinarine (34), resveratrol (35), triptolide (36) or EGCG (37), had no effect on IFN- $\gamma$-induced expressions of MIG, IP-10 and I-TAC in INS-1 cells (Fig. 5). These results indicate that SFN may have a unique structural moiety leading to a strong inhibitory effect on the IFN- $\gamma$-induced expression of MIG, IP-10 and I-TAC in INS-1 cells.

In conclusion, the findings of our study collectively demonstrate the ability of SFN to strongly inhibit the IFN- $\gamma$-induced expression of MIG, IP-10 and I-TAC in INS-1 cells through the reduced expression and phosphorylation levels of IRF-1, STAT-1 and PKB. Although there are still important issues that remain to be resolved, including the suppressive effects of SFN on the expression of chemokines in animal models of islet inflammation, the present findings suggest that SFN may be a promising natural product for use against pancreatic islet inflammation in which the overexpression of T-cell chemokines is problematic.

\section{Acknowledgements}

This study was supported by the research promoting grant from the Keimyung University Dongsan Medical Center in 2009.

\section{References}

1. Salgame P, Abrams JS, Clayberger C, Goldstein H, Convit J, Modlin RL and Bloom BR: Differing lymphokine profiles of functional subsets of human CD4 and CD8 T cell clones. Science 254: 279-282, 1991.

2. Neville LF, Mathiak G and Bagasra O: The immunobiology of interferon-gamma inducible protein $10 \mathrm{kD}$ (IP-10): A novel, pleiotropic member of the C-X-C chemokine superfamily. Cytokine Growth Factor Rev 8: 207-219, 1997.

3. Farber JM: Mig and IP-10: CXC chemokines that target lymphocytes. J Leukoc Biol 61: 246-257, 1997.

4. Cole KE, Strick CA, Paradis TJ, Ogborne KT, Loetscher M, Gladue RP, Lin W, Boyd JG, Moser B, Wood DE, et al: Interferon-inducible $\mathrm{T}$ cell alpha chemoattractant (I-TAC): A novel non-ELR CXC chemokine with potent activity on activated $\mathrm{T}$ cells through selective high affinity binding to CXCR3. J Exp Med 187: 2009-2021, 1998. 
5. Liu MT, Armstrong D, Hamilton TA and Lane TE: Expression of Mig (monokine induced by interferon-gamma) is important in $\mathrm{T}$ lymphocyte recruitment and host defense following viral infection of the central nervous system. J Immunol 166: 1790-1795, 2001.

6. Bonecchi R, Bianchi G, Bordignon PP, D'Ambrosio D, Lang R, Borsatti A, Sozzani S, Allavena P, Gray PA, Mantovani A, et al: Differential expression of chemokine receptors and chemotactic responsiveness of type $1 \mathrm{~T}$ helper cells (Th1s) and Th2s. J Exp Med 187: 129-134, 1998.

7. Groom JR and Luster AD: CXCR3 in T cell function. Exp Cell Res 317: 620-631, 2011.

8. Nakayama M, Abiru N, Moriyama H, Babaya N, Liu E, Miao D, Yu L, Wegmann DR, Hutton JC, Elliott JF, et al: Prime role for an insulin epitope in the development of type 1 diabetes in NOD mice. Nature 435: 220-223, 2005.

9. Michelsen BK, Petersen JS, Boel E, Møldrup A, Dyrberg T and Madsen OD: Cloning, characterization, and autoimmune recognition of rat islet glutamic acid decarboxylase in insulindependent diabetes mellitus. Proc Natl Acad Sci USA 88 8754-8758, 1991.

10. Bonifacio E, Lampasona V, Genovese S, Ferrari M and Bosi E Identification of protein tyrosine phosphatase-like IA2 (islet cell antigen 512) as the insulin-dependent diabetes-related $37 / 40 \mathrm{~K}$ autoantigen and a target of islet-cell antibodies. J Immunol 155 5419-5426, 1995.

11. Graham KL, Krishnamurthy B, Fynch S, Ayala-Perez R, Slattery RM, Santamaria P, Thomas HE and Kay TW: Intra-islet proliferation of cytotoxic T lymphocytes contributes to insulitis progression. Eur J Immunol 42: 1717-1722, 2012.

12. Roep BO, Kleijwegt FS, van Halteren AG, Bonato V, Boggi U, Vendrame F, Marchetti P and Dotta F: Islet inflammation and CXCL10 in recent-onset type 1 diabetes. Clin Exp Immunol 159: 338-343, 2010.

13. Heiss E, Herhaus C, Klimo K, Bartsch H and Gerhäuser C: Nuclear factor kappa B is a molecular target for sulforaphanemediated anti-inflammatory mechanisms. J Biol Chem 276 32008-32015, 2001.

14. Rose P, Huang Q, Ong CN and Whiteman M: Broccoli and watercress suppress matrix metalloproteinase- 9 activity and invasiveness of human MDA-MB-231 breast cancer cells. Toxicol Appl Pharmacol 209: 105-113, 2005.

15. Lin W, Wu RT, Wu T, Khor TO, Wang H and Kong AN: Sulforaphane suppressed LPS-induced inflammation in mouse peritoneal macrophages through Nrf2 dependent pathway. Biochem Pharmacol 76: 967-973, 2008.

16. Zhao J, Moore AN, Redell JB and Dash PK: Enhancing expression of Nrf2-driven genes protects the blood brain barrier after brain injury. J Neurosci 27: 10240-10248, 2007.

17. Annabi B, Rojas-Sutterlin S, Laroche M, Lachambre MP, Moumdjian R and Béliveau R: The diet-derived sulforaphane inhibits matrix metalloproteinase-9-activated human brain microvascular endothelial cell migration and tubulogenesis. Mol Nutr Food Res 52: 692-700, 2008.

18. Schroder K,Hertzog PJ,Ravasi Tand Hume DA: Interferon-gamma: An overview of signals, mechanisms and functions. J Leukoc Biol 75: 163-189, 2004.

19. Lu X, Masic A, Liu Q and Zhou Y: Regulation of influenza A virus induced CXCL-10 gene expression requires PI3K/Akt pathway and IRF3 transcription factor. Mol Immunol 48: 1417-1423, 2011.

20. Jaruga B, Hong F, Kim WH and Gao B: IFN-gamma/STAT1 acts as a proinflammatory signal in $\mathrm{T}$ cell-mediated hepatitis via induction of multiple chemokines and adhesion molecules: A critical role of IRF-1. Am J Physiol Gastrointest Liver Physiol 287: G1044-G1052, 2004.
21. Capua I, Mercalli A, Pizzuto MS, Romero-Tejeda A, Kasloff S, De Battisti C, Bonfante F, Patrono LV, Vicenzi E, Zappulli V, et al: Influenza A viruses grow in human pancreatic cells and cause pancreatitis and diabetes in an animal model. J Virol 87: 597-610, 2013.

22. Christen U, McGavern DB, Luster AD, von Herrath MG and Oldstone MB: Among CXCR3 chemokines, IFN-gammainducible protein of $10 \mathrm{kDa}$ (CXC chemokine ligand (CXCL) 10) but not monokine induced by IFN-gamma (CXCL9) imprints a pattern for the subsequent development of autoimmune disease. J Immunol 171: 6838-6845, 2003.

23. Westwell-Roper C, Nackiewicz D, Dan M and Ehses JA: Toll-like receptors and NLRP3 as central regulators of pancreatic islet inflammation in type 2 diabetes. Immunol Cell Biol 92: 314-323, 2014.

24. Burke SJ and Collier JJ: Insulitis and diabetes: A perspective on islet inflammation. Immunome Res S2: e002, 2014.

25. Baker RG, Hayden MS and Ghosh S: NF- $\mathrm{BB}$, inflammation, and metabolic disease. Cell Metab 13: 11-22, 2011.

26. Darnell JE Jr, Kerr IM and Stark GR: Jak-STAT pathways and transcriptional activation in response to IFNs and other extracellular signaling proteins. Science 264: 1415-1421, 1994.

27. Aaronson DS and Horvath CM: A road map for those who don't know JAK-STAT. Science 296: 1653-1655, 2002.

28. O'Shea JJ, Gadina M and Schreiber RD: Cytokine signaling in 2002: New surprises in the Jak/Stat pathway. Cell 109 (Suppl): S121-S131, 2002.

29. Guerrero-Beltrán CE, Mukhopadhyay P, Horváth B, Rajesh M, Tapia E, García-Torres I, Pedraza-Chaverri J and Pacher P: Sulforaphane, a natural constituent of broccoli, prevents cell death and inflammation in nephropathy. J Nutr Biochem 23: 494-500, 2012.

30. Devi JR and Thangam EB: Mechanisms of anticancer activity of sulforaphane from Brassica oleracea in HEp-2 human epithelial carcinoma cell line. Asian Pac J Cancer Prev 13: 2095-2100, 2012.

31. Jeong SI, Choi BM and Jang SI: Sulforaphane suppresses TARC/CCL17 and MDC/CCL22 expression through heme oxygenase- 1 and NF- $\mathrm{BB}$ in human keratinocytes. Arch Pharm Res 33: 1867-1876, 2010.

32. Saha B, Jyothi Prasanna S, Chandrasekar B and Nandi D: Gene modulation and immunoregulatory roles of interferon gamma. Cytokine 50: 1-14, 2010.

33. Zhong F, Chen H, Han L, Jin Y and Wang W: Curcumin attenuates lipopolysaccharide-induced renal inflammation. Biol Pharm Bull 34: 226-232, 2011.

34. Niu X, Fan T, Li W, Xing W and Huang H: The anti-inflammatory effects of sanguinarine and its modulation of inflammatory mediators from peritoneal macrophages. Eur J Pharmacol 689: 262-269, 2012.

35. Park DW, Kim JS, Chin BR and Baek SH: Resveratrol inhibits inflammation induced by heat-killed Listeria monocytogenes. J Med Food 15: 788-794, 2012.

36. Hongqin T, Xinyu L, Heng G, Lanfang X, Yongfang W and Shasha S: Triptolide inhibits IFN- $\gamma$ signaling via the Jak/STAT pathway in HaCaT keratinocytes. Phytother Res 25: 1678-1685, 2011.

37. Yang J, Han Y, Chen C, Sun H, He D, Guo J, Jiang B, Zhou L and Zeng C: EGCG attenuates high glucose-induced endothelial cell inflammation by suppression of PKC and NF- $\mathrm{KB}$ signaling in human umbilical vein endothelial cells. Life Sci 92: 589-597, 2013. 